\title{
Susceptibility of Kintoki Bean Lectin to Digestive Enzymes in vitro and Its Behavior in the Digestive Organs of Mouse in vivo
}

\author{
Tomoko HARA, ${ }^{1}$ Yōko MuKunOKI, ${ }^{2}$ Ikuyo TsUKAMOTo, ${ }^{1}$ \\ Masamitsu MIYOSHI, ${ }^{2}$ and Kiyozo HASEGAWA ${ }^{1}$ \\ ${ }^{1}$ Graduate Division of Human Culture (Doctoral Degree Program), \\ Nara Women's University, Nara 630, Japan \\ ${ }^{2}$ Laboratory of Nutritional Chemistry, Department of Food Science \\ and Nutrition, Nara Women's University, Nara 630, Japan
}

(Received November 26, 1983)

\begin{abstract}
Summary The enzymatic digestion of a Kintoki bean lectin in vitro resulted in neither the extensive hydrolysis nor complete inactivation of the lectin. The majority of $\left[{ }^{3} \mathrm{H}\right]$ lectin administered to mice by stomachintubation was found in the digestive tract at levels of $88.7 \%, 99.4 \%$, $99.5 \%$ and $78.6 \%$, after $0.5,2,5$ and $24 \mathrm{~h}$ of intubation, respectively. Twenty to forty percent of the administered radioactivity was found combined with the mucosa of the small intestine. After $24 \mathrm{~h}$ of intubation, part of the radioactivity was found in the feces. The recovery test of hemagglutinating activity and the molecular weight determination of the lectin administered to and recovered from mice revealed that more than $70 \%$ of the radioactivity detected in the digestive tract represented intact lectin.

Therefore, it was concluded that most of the Kintoki bean lectin survived its passage through the gastrointestinal tract. The lectin-binding sites in the intestinal mucosa were traced with fluorescence microscopy using the lectin conjugated with fluorescein isothiocyanate. The fluorescent sites were found located at the top and upper sites of the villi, but not at the crypt.

Key Words Kintoki bean, toxic lectin, digestion of lectin, behavior of lectin in digestive tract, binding of lectin to intestine, lectin labeled with ${ }^{3} \mathrm{H}$ and FITC
\end{abstract}

Beans are regarded as an important source of vegetable proteins and have been consumed more and more widely. However, it has long been known that diets containing raw beans cause a significant impairment of animal growth and other noteworthy symptoms of toxicity $(1-6)$. The anti-nutritive factors identified in beans

${ }^{1}$ 原 知子, ${ }^{2}$ 椋 容子, ${ }^{1}$ 塚本幾代, ${ }^{2}$ 三好正満, ${ }^{1}$ 長谷川喜代三 
include protease inhibitors, lectins (hemagglutinins), anti-niacin factor, polyphenolic compounds etc. (7).

We have directed our attention to a lectin contained in Kintoki beans (Phaseolus vulgaris) and confirmed that the purified Kintoki bean lectin impairs the growth of mice to an extent directly proportional to its dose (8). On the other hand, soybean lectin was reported to be rapidly cleaved by pepsin and thereby to be least toxic $(6,9)$. A storage protein of Phaseolus beans was reported to be less susceptible to hydrolysis by proteases in vitro than bovine serum albumin (10). Brady et al. reported that intact wheat germ lectin was detected in human intestinal contents (11). These facts indicate that lectins hardly attacked by enzymes have the opportunity of exhibiting such a toxicity in the digestive tract as the disruption of the intestinal villi of rats $(8,12)$.

In order to investigate whether such toxicity is directly due to some biological function of intact lectins, it should be necessary to look into the detailed behavior and action of pure lectins in the digestive tract. In recent years, a rapid increase of our knowledge of lectins has been brought about in the biological, biochemical and clinical fields (13). In the nutritional studies of lectins, however, crude preparations of lectins have been commonly used and therefore some ambiguity cannot be avoided in the interpretation of experimental results. Our previous observation on the physiological functions of the lectin purified from Kintoki bean indicated that the lectin is toxic to cultured cells and animals, that the first target of its oral toxicity is the small intestine and that this lectin must be stable enough to display its toxic activities in the digestive tract $(14,15)$. In this study we examined the resistance in vitro of the Kintoki bean lectin to several digestive enzymes and its behavior in vivo in the digestive tract of mice.

\section{METHODS}

Hemagglutination assay. A toxic lectin was isolated from Kintoki beans (Phaseolus vulgaris) as previously described(16). Hemagglutination tests were carried out on microtiter plates with 2 -fold serial dilution of samples and $2 \%$ suspension of mouse erythrocytes. The amount of samples per $\mathrm{ml}$ in the last dilution of visually detectable agglutination was defined as one unit of hemagglutinating activity.

High-performance liquid chromatography. Gel filtration was performed on a Protein Column I-250 (exclusive $\mathrm{MW}=250,000$, Waters Co., $30.5 \mathrm{~cm} \times 1 \mathrm{~cm}$ ) connected to an instrument for HPLC (Shimadzu Co.). Thirty microliters of samples were injected into the column and eluted at a room temperature with $0.28 \mathrm{M}$ potassium phosphate buffer, $\mathrm{pH} 6.0$, at a flow rate of $0.8 \mathrm{ml}$ per min. The eluates were monitored at $280 \mathrm{~nm}$ and the peak areas were calculated with a computer-laid recorder (Chromatopac, C-R1A, Shimadzu). The area of a peak occurring at approximately $11 \mathrm{~min}$ after injection was used for the quantification of the intact lectin and hemagglutinating activity of which did not change after labeling. 
Lectin labeling. 1) Labeling with ${ }^{3} \mathrm{H}: \quad N$-Succinimidyl $\left[2,3-{ }^{3} \mathrm{H}\right]$ propionate $(500 \mu \mathrm{Ci})$ and lectin $(5 \mathrm{mg})$ were mixed in $1 \mathrm{ml}$ of $20 \mathrm{mM}$ sodium phosphate buffer, pH 7.4, and left standing at $25^{\circ} \mathrm{C}$ for $3 \mathrm{~h}(17)$. The solution was then applied on a Sephadex G-50 column to obtain $\left[{ }^{3} \mathrm{H}\right]$ lectin eluted prior to unreacted propionate.

2) Labeling with FITC: Lectin $(12.5 \mathrm{mg} / \mathrm{ml})$ and fluorescein isothiocyanate $(0.62 \mathrm{mg} / \mathrm{ml}$, Isomer I, Sigma) were mixed in $0.1 \mathrm{M}$ borate buffer, $\mathrm{pH} 8.3$, and allowed to react at $5^{\circ} \mathrm{C}$ for $15 \mathrm{~h}$ in the dark (18). Free dye was removed by gel filtration on a Sephadex G-50 column. The binding ratio of FITC to lectin, $F / P$, was calculated from the absorbances at $280 \mathrm{~nm}$ and $494 \mathrm{~nm}$ using the formula;

$$
\frac{F}{P}=\frac{A_{494}}{A_{280}-(2 / 7) A_{494}}
$$

FITC-conjugated lectins having $F / P$ values smaller than 0.5 were used in the present experiment because the agglutinating activity of the lectin decreased as the $F / P$ value became higher than 1 .

Digestion in vitro. Lectin $(2 \mathrm{mg} / \mathrm{ml}$ ) and pepsin (from hog stomach mucosa, SIGMA A, $0.04 \mathrm{mg} / \mathrm{ml}$ ) were incubated at $37^{\circ} \mathrm{C}$ in $0.01 \mathrm{M} \mathrm{HCl}$ solution. After 2 or $4 \mathrm{~h}$ of incubation, $0.1 \mathrm{ml}$ and $0.5 \mathrm{ml}$ portions of the incubation mixture were withdrawn for HPLC and hemagglutination assay, the results of which were compared with those for the control lectin not treated with pepsin. Trypsin (from bovine pancreas, SIGMA type I) and $\alpha$-chymotrypsin (from bovine pancreas, SIGMA type II) were dissolved in $1 / 15 \mathrm{M}$ sodium phosphate buffer, $\mathrm{pH} 7.6$, and cathepsin D (from bovine spleen, SIGMA) in $0.01 \mathrm{M}$ sodium citrate buffer, $\mathrm{pH} 2.8$. The digestion procedures with these enzymes were the same as in the case of pepsin except for the buffers used. In addition, lectin was exposed to two types of enzymes successively, pepsin plus trypsin or pepsin plus chymotrypsin, in the following way. At first, lectin $(2 \mathrm{mg} / \mathrm{ml})$ and pepsin $(0.04 \mathrm{mg} / \mathrm{ml})$ were incubated in $0.01 \mathrm{M} \mathrm{HCl}$ solution for 0.5 or $2 \mathrm{~h}$. Then the $\mathrm{pH}$ of the incubation mixture was adjusted to 7.6 with $0.2 \mathrm{~N} \mathrm{NaOH}$, and trypsin or chymotrypsin $(0.02 \mathrm{mg} / \mathrm{ml})$ in $1 / 15 \mathrm{M}$ sodium phosphate buffer, $\mathrm{pH} 7.6$, was added to the mixture. The second digestion was carried out for 0.5 or $2 \mathrm{~h}$. Assay of hemagglutinating activity and HPLC were performed in the same way as described above.

Behavior in vivo. 1) Distribution of radioactivity in mouse after stomachintubation of $\left[{ }^{3} \mathrm{H}\right]$ lectin: Mice (ddY, male, 4 weeks old) were fasted in advance for about $20 \mathrm{~h}$. $\left[{ }^{3} \mathrm{H}\right]$ Lectin and $10 \mathrm{mg}$ of cold lectin were dissolved in $1 \mathrm{ml}$ of distilled water $\left(2 \times 10^{6} \mathrm{cpm} / \mathrm{ml}\right)$. This sample $(1 \mathrm{ml})$ was given to each mouse by stomachintubation and two mice each were sacrificed by decapitation after $0.5,2,5$ and $24 \mathrm{~h}$ of intubation, respectively. Liver, kidney, pancrease, brain, lung, thymus, spleen, stomach, small intestine, caecum and large intestine were excised. The small intestine was divided into three sections of $12 \mathrm{~cm}$ length which were named small intestine 1, 2 and 3 from the pylorus to distal intestine. The contents were rinsed out with cold phosphate buffered saline (PBS) from each segment of the gastrointestinal tissues. The rinsing procedure was repeated twice. The washing fluids and the 
intestinal contents were pooled as for the samples containing free lectins. The residual gastrointestinal tissues and the other excised organs were homogenized in ice-cold PBS in a Potter's homogenizer and made up to a fixed volume. Blood was collected at decapitation. Urine and feces were collected during chasing periods. A one-tenth milliliter portion of each sample was treated with hydrogen peroxide and completely dissolved in Soluen-350 (Packard Co.). An aliquot of the resultant solution was mixed with a toluene-based liquid scintillator. The radioactivity was measured in a Packard Tricarb 3375 liquid scintillation spectrometer. A part of the homogenized specimens was dissolved in $1 \%$ sodium dodecyl sulfate (SDS) followed by treatment with mercaptoethanol, and the resultant mixture was subjected to discontinuous SDS $10 \%$ polyacrylamide gel electrophoresis. Gels were cut into pieces of $5 \mathrm{~mm}$ length. To each piece, $0.5 \mathrm{ml}$ of hydroperoxide was added, followed by incubation in a bial at $50^{\circ} \mathrm{C}$ overnight to dissolve the gel completely for the determination of radioactivity. As the mobility of the intact Kintoki bean lectin was 0.4 subunit $\mathrm{MW}=35,000$ ), it was calculated from the recovery of the radioactivity from the gel pieces at $0.35-0.45$ mobility how much radioactivity of each sample represented intact lectin.

2) Hemagglutinating activity of the lectins recovered from digestive tract: Mice were fasted for $20 \mathrm{~h}$. To each mouse was administered $10 \mathrm{mg}$ of lectin in $0.8 \mathrm{ml}$ water by stomach-intubation and two mice each were sacrificed by decapitation after 2, 5 and $24 \mathrm{~h}$ of intubation, respectively. Stomach, small intestine, caecum and large intestine were excised and washed with cold PBS. The contents of the digestive tract and the rinsed fluids were homogenized in a cold PBS as described above and centrifuged to collect the extracts containing free lectin. Lectin bound to the mucosa of the small intestine could not be subjected to hemagglutination assay because of the lack of reagents for releasing it from the mucosa. Urine and feces were collected for the assay of hemagglutinating activity. The recovery in activity was calculated from the total units recovered in the samples against the total units ingested by each mouse.

Binding in vitro to intestinal tissues. 1) Time course: Mice were sacrificed by decapitation after fasting for $20 \mathrm{~h}$. Segments of $2 \mathrm{~cm}$ length were prepared from the small intestine $10-15 \mathrm{~cm}$ distal to the pylorus and placed in Krebs glucose medium (KGM) equilibrated with $95 \% \mathrm{O}_{2}$ and $5 \% \mathrm{CO}_{2}$. The intestinal segments were everted, blotted and weighed. They were exposed at $37^{\circ} \mathrm{C}$ to the $\left[{ }^{3} \mathrm{H}\right]$ lectin solutions having the concentrations of either 10,227 or $500 \mu \mathrm{g} / \mathrm{ml}$ in $\mathrm{KGM}(60,000-70,000$ $\mathrm{cpm} / \mathrm{ml}$ ). After 15, 30, 45 and $60 \mathrm{~min}$ of exposure, they were removed from the media, rinsed in $2 \mathrm{ml} \mathrm{KGM}$ and centrifuged. This washing procedure was repeated twice. The washed segments were dissolved in $1 \mathrm{ml}$ of Soluen-350 for the measurement of radioactivity.

2) Binding to different parts of small intestine: $\left[{ }^{3} \mathrm{H}\right]$ Lectin and cold lectin were dissolved in $\mathrm{KGM}$ so as to make the concentrations of $1,2,4$ and $8 \mathrm{mg}$ per ml $\left(1.8 \times 10^{5} \mathrm{cpm} / \mathrm{ml}\right)$. The small intestine was excised from mice fasted for $20 \mathrm{~h}$ and divided into three parts of equal length which were named 1, 2 and 3, starting from 
the one adjacent to the pylorus. Two everted segments of $1 \mathrm{~cm}$ length were prepared from each part, blotted, and weighed as quickly as possible. Each segment was exposed to one of the above lectin solutions at $25^{\circ} \mathrm{C}$ for $30 \mathrm{~min}$ under an atmosphere of $95 \% \mathrm{O}_{2}$ and $5 \% \mathrm{CO}_{2}$. The amounts of lectin bound to the intestinal tissues were determined as described above.

Microscopic observation of the lectin binding to intestinal mucosa. 1) Binding in vivo: Ten milligrams of FITC-conjugated lectin in $1 \mathrm{ml}$ of PBS was ingested, via a stomach-tube, by a mouse fasted for $20 \mathrm{~h}$. Two hours later, the mouse was anesthetized and an intestinal segment $5 \mathrm{~cm}$ distal to the pylorus was excised. The segment was rinsed in PBS and frozen to prepare $10 \mu \mathrm{m}$ sections for microscopic observation using a thermoelectric freezing unit for microtome (Komatsu Electronics Inst.). The fluorescence due to FITC in the sections was observed under a light microscope (Olympus BH2) using an FITC interference filter.

2) Binding in vitro: Ten micrometer sections of the small intestine of a mouse not administered with FITC-lectin were prepared in the same way as described above. About $200 \mu \mathrm{l}$ of an FITC-lectin solution $(\mathrm{mg} / \mathrm{ml})$ were mounted on the sections on slide glasses and kept for $20 \mathrm{~min}$ at room temperature. The lectin solution was blotted off and the sections were rinsed three to four times in PBS before microscopic observation.

\section{RESULTS AND DISCUSSION}

\section{Digestion in vitro}

The hemagglutinating activity of Kintoki bean lectin was not affected after $2 \mathrm{~h}$ of digestion by any of the four enzymes. After $4 \mathrm{~h}$ of incubation, the activity was least reduced by pepsin and cathepsin, but lowered to the extents of one to two well difference on a titer plate by trypsin and chymotrypsin. Table 1 shows the results obtained with an enzyme versus lectin ratio of $1: 50$, by weight.

Results obtained with other ratios of 1 to 20 or 1 to 100 were similar to those for the 1 to 50 ratio (data not shown). In the right-hand column in Table 1 are shown the recoveries of intact lectin as measured by gel filtration on HPLC. The recovery was $100 \%$ or very nearly, as far as the hemagglutinating activity remained unchanged, but resulted in a detectable decrease to about $87 \%$ in the 4-h digestion with trypsin or chymotrypsin where the hemagglutinating activity also decreased to a noticeable extent. However, the decrease by titer 1 in the hemagglutinating activity should be accompanied theoretically by an approximate $50 \%$ change in the recovery of intact lectin on gel filtration. The absence of quantitative correlation between the present two measurements is probably due to the semiquantitative data on hemagglutinating activity obtained by the naked eye. Successive digestion with pepsin and trypsin or with pepsin and chymotrypsin gave results similar to those obtained by the digestion with the individual enzyme. Consequently, the susceptibility of Kintoki bean lectin to trypsin or chymotrypsin does not appear to change after treatment with pepsin, indicating that the lectin is highly resistant to pepsin. It

Vol. 30, No. 4, 1984 
Table 1. Hemagglutinating activity ( $1 \%$ mouse blood cells) and peak recovery on HPLC after enzymatic digestion of Kintoki bean lectin (enzyme/lectin $(w / w)=1 / 50$ ).

\begin{tabular}{|c|c|c|c|c|c|c|c|c|c|c|c|c|}
\hline \multirow{2}{*}{ Enzyme } & \multirow{2}{*}{ Time (h) } & \multicolumn{10}{|c|}{ Titer } & \multirow{2}{*}{$\begin{array}{l}\text { Recovery on } \\
\text { HPLC }(\%)^{a}\end{array}$} \\
\hline & & $2^{0}$ & $2^{1}$ & $2^{2}$ & $2^{3}$ & $2^{4}$ & $2^{5}$ & $2^{6}$ & $2^{7}$ & $2^{8}$ & $2^{9}$ & \\
\hline Control & - & ++ & ++ & ++ & ++ & + & + & \pm & - & - & - & 100.0 \\
\hline Pepsin & $\begin{array}{l}2 \\
4\end{array}$ & $\begin{array}{l}++ \\
++\end{array}$ & $\begin{array}{l}++ \\
++\end{array}$ & $\begin{array}{l}++ \\
++\end{array}$ & $\begin{array}{l}+ \\
+\end{array}$ & $\begin{array}{l}+ \\
+\end{array}$ & $\begin{array}{l}+ \\
+\end{array}$ & $\begin{array}{l} \pm \\
\pm\end{array}$ & - & - & - & $\begin{array}{r}96.0 \\
100.0\end{array}$ \\
\hline Trypsin & $\begin{array}{l}2 \\
4\end{array}$ & $\begin{array}{l}++ \\
++\end{array}$ & $\begin{array}{l}++ \\
++\end{array}$ & $\begin{array}{l}++ \\
++ \\
++\end{array}$ & $\begin{array}{l}+ \\
+ \\
+\end{array}$ & $\begin{array}{l}+ \\
+ \\
+\end{array}$ & $\begin{array}{l}+ \\
+ \\
\pm\end{array}$ & $\begin{array}{l} \pm \\
\pm \\
-\end{array}$ & $\begin{array}{l}- \\
- \\
-\end{array}$ & $\begin{array}{l}- \\
-\end{array}$ & $\begin{array}{l}- \\
-\end{array}$ & $\begin{array}{r}98.3 \\
86.8\end{array}$ \\
\hline Chymotrypsin & $\begin{array}{l}2 \\
4\end{array}$ & $\begin{array}{l}++ \\
++\end{array}$ & $\begin{array}{l}++ \\
++\end{array}$ & $\begin{array}{l}++ \\
++\end{array}$ & $\begin{array}{l}+ \\
+\end{array}$ & $\begin{array}{l}+ \\
+\end{array}$ & + & $\begin{array}{l} \pm \\
\pm\end{array}$ & $\begin{array}{l}- \\
-\end{array}$ & - & $\begin{array}{l}- \\
-\end{array}$ & $\begin{array}{r}100.0 \\
87.4\end{array}$ \\
\hline Cathepsin & $\begin{array}{l}2 \\
4\end{array}$ & $\begin{array}{l}++ \\
++\end{array}$ & $\begin{array}{l}++ \\
++\end{array}$ & $\begin{array}{l}++ \\
++\end{array}$ & $\begin{array}{l}+ \\
+\end{array}$ & $\begin{array}{l}+ \\
+\end{array}$ & $\begin{array}{l}+ \\
+\end{array}$ & $\begin{array}{l} \pm \\
\pm\end{array}$ & $\begin{array}{l}- \\
-\end{array}$ & $\begin{array}{l}- \\
-\end{array}$ & $\begin{array}{l}- \\
-\end{array}$ & $\begin{array}{l}100.0 \\
100.0\end{array}$ \\
\hline $\begin{array}{l}\text { Pepsin } \\
\text { trypsin }\end{array}$ & $\begin{array}{l}0.5 \\
0.5\end{array}$ & ++ & ++ & ++ & + & + & + & \pm & - & - & - & 99.5 \\
\hline $\begin{array}{l}\text { Pepsin } \\
\text { trypsin }\end{array}$ & $\begin{array}{l}2 \\
2\end{array}$ & ++ & ++ & ++ & + & + & + & \pm & - & - & - & 97.5 \\
\hline $\begin{array}{l}\text { Pepsin } \\
\text { chymotrypsin }\end{array}$ & $\begin{array}{l}0.5 \\
0.5\end{array}$ & ++ & ++ & ++ & + & + & + & \pm & - & - & - & 98.8 \\
\hline $\begin{array}{l}\text { Pepsin } \\
\text { chymotrypsin }\end{array}$ & $\begin{array}{l}2 \\
2\end{array}$ & ++ & ++ & ++ & + & + & + & \pm & - & - & - & 93.1 \\
\hline
\end{tabular}

${ }^{\text {a }}$ The recovery was calculated from the area of peak corresponding to intact lectih.

was reported that soybean lectin was rapidly hydrolyzed by pepsin, but that Phaseolus vulgaris lectin was not completely inactivated even after 6 days of incubation with pepsin(9). Thus the lower toxicity of soybean lectin can be explained by its higher vulnerability to digestive enzymes. In view of the relatively high resistance to digestive enzymes, Kintoki bean lectin seems to have a chance of exhibiting its toxicity in the digestive tract before being hydrolyzed in vivo.

\section{Behavior in vivo}

1) Distribution of radioactivity in mouse after stomach-intubation of $\left[{ }^{3} \mathrm{H}\right] \mathrm{lectin}$. Conditions of enzymatic digestion in vitro apparently differ from those in vivo, particularly in the varieties and quantities of enzymes involved. Hence, it is not certain whether the high resistance of Kintoki bean lectin against digestive enzymes found in vitro in the present study is applicable to the in vivo cases. Therefore, we administered $\left[{ }^{3} \mathrm{H}\right]$ lectin to mice by stomach-intubation in order to investigate the behavior of the lectin in the gut. At $0.5,2,5$ and $24 \mathrm{~h}$ after the ingestion of $\left[{ }^{3} \mathrm{H}\right]$ lectin $\left(10 \mathrm{mg}, 2 \times 10^{6} \mathrm{cpm}\right)$, the radioactivities in various organs, blood, urine, and feces were counted (Table 2). The count recoveries from whole body were $88.7 \%, 99.4 \%$, $99.5 \%$, and $78.6 \%$ after $0.5,2,5$ and $24 \mathrm{~h}$ of intubation, respectively. The majority of the ingested lectin was found in the digestive tract within the experimental periods; 
Table 2. Distribution of radioactivity in mouse after stomach-intubation of $\left[{ }^{3} \mathrm{H}\right]$ lectin ${ }^{b}$ $(\%)$.

\begin{tabular}{|c|c|c|c|c|}
\hline \multirow{2}{*}{ Organ } & \multicolumn{4}{|c|}{ Time (h) } \\
\hline & 0.5 & 2 & 5 & 24 \\
\hline Main organs ${ }^{a}$ & $1.3 \pm 0.2$ & $2.5 \pm 0.9$ & $2.8 \pm 0.3$ & $3.2 \pm 0.1$ \\
\hline Blood & $0.1 \pm 0.0$ & $0.4 \pm 0.4$ & $0.8 \pm 0.6$ & $2.0 \pm 0.0$ \\
\hline Urine & - & - & $8.8 \pm 1.8$ & $3.0 \pm 0.1$ \\
\hline Feces & - & - & - & $12.0 \pm 2.5$ \\
\hline Digestive tract free & $65.8 \pm 12.2$ & $57.1 \pm 0.5$ & $60.0 \pm 10.2$ & $40.3 \pm 1.0$ \\
\hline bound & $21.7 \pm 3.7$ & $39.4 \pm 2.5$ & $27.2 \pm 12.3$ & $18.2 \pm 0.4$ \\
\hline Total recovery & $88.7 \pm 16.0$ & $99.4 \pm 0.7$ & $99.5 \pm 0.7$ & $78.6 \pm 1.4$ \\
\hline
\end{tabular}

${ }^{a}$ Main organs: kidney, liver, spleen, pancreas, brain, lung, heart and thymus. ${ }^{b}\left[{ }^{3} \mathrm{H}\right]$ Lectin $\left(10 \mathrm{mg}, 2 \times 10^{6} \mathrm{cpm}\right)$ was intubated to each mouse.

Table 3. Percentages of intact lectin ${ }^{a}$ in each part of digestive tract determined by SDS polyacrylamide gel electrophoresis (\%).

\begin{tabular}{|c|c|c|c|c|c|c|c|c|}
\hline \multirow{3}{*}{ Organ } & \multicolumn{8}{|c|}{ Time (h) } \\
\hline & \multicolumn{2}{|c|}{0.5} & \multicolumn{2}{|c|}{2} & \multicolumn{2}{|c|}{5} & \multicolumn{2}{|c|}{24} \\
\hline & Free & Bound & Free & Bound & Free & Bound & Free & Bound \\
\hline Stomach & 99.5 & - & 98.2 & 97.7 & 98.8 & - & - & - \\
\hline Small intestine 1 & 99.3 & 99.0 & 99.2 & 98.6 & 96.5 & 94.6 & 95.0 & 93.0 \\
\hline 2 & 98.7 & 96.9 & 97.5 & 99.4 & 97.7 & 92.7 & 96.2 & 98.0 \\
\hline 3 & 99.8 & 93.6 & 99.6 & 99.7 & 99.5 & 90.3 & 96.2 & 98.0 \\
\hline Caecum & 93.4 & 97.0 & 88.7 & 96.1 & 83.7 & 94.5 & 69.6 & 96.1 \\
\hline Large intestine & - & - & 96.3 & 93.1 & 83.9 & 89.5 & 70.8 & 90.0 \\
\hline Faces & - & - & - & - & - & - & 65.3 & - \\
\hline
\end{tabular}

${ }^{\text {a }}$ The ratio was calculated from the counts from the gel segments corresponding to 0.35 0.45 mobility.

$87.5 \%, 96.5 \%, 97.2 \%$ and $58.4 \%$ after $0.5,2,5$ and $24 \mathrm{~h}$ of intubation, respectively. High counts indicated considerable binding to the intestine. The binding ratio reached a maximum of $39.4 \%$ of the total lectin administered at $2 \mathrm{~h}$ and gradually decreased to $18.2 \%$ at $24 \mathrm{~h}$. Counts became detectable in feces at $24 \mathrm{~h}$. However, these radioactivities might be due to some hydrolyzed lectins.

To make this point clear, aliquots of all the samples were subjected to SDS $10 \%$ polyacrylamide gel electrophoresis. In the samples other than those from the 

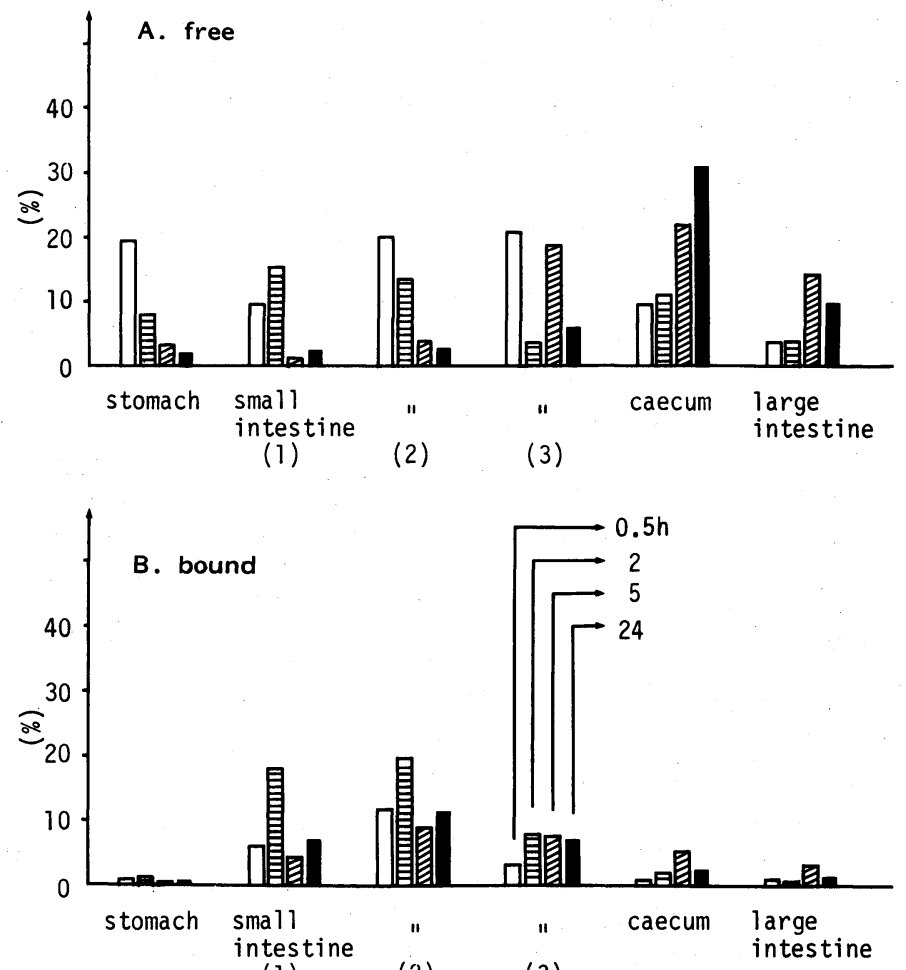

(1)

(2)

(3)

Fig. 1. Distribution of radioactivity in the digestive tract of mice given $\left[{ }^{3} \mathrm{H}\right]$ lectin. Total radioactivity in the digestive tract was taken as $100 \%$. The values were corrected for the recovery on SDS polyacrylamide gel electrophoresis to represent the ratios due only to intact lectin.

digestive tract and feces, few counts were found at the mobility of 0.4 where intact Kintoki bean lectin was to be located, but significant counts at the mobilities higher than 0.4. Therefore, we assume, as regards our detectability, that most of the radioactive materials absorbed by mice may not represent intact lectin. This is in contrast to the findings of Putzai et al. that an immune-precipitate from the serum of rat fed kidney bean contained the subunit of lectin (19). Results obtained with the samples from the digestive tract and feces are summarized in Table 3. Most of the values in Table 3 are over $90 \%$ indicating that the ingested lectin is fairly stable in vivo. But in the contents of the caecum, the radioactivity at around a mobility of 0.4 representing $88.7 \%$ for 2 -h fragments, was detected at mobilities of $0.6-0.8$ in these samples. Similar results were obtained with samples from the large intestine. In the caecum, the large intestine and the feces, part of the lectin was apparently decomposed by enzymatic and probably bacterial actions. Figure 1 shows the distribution patterns of intact lectin (free and bound) in the digestive tract of mice at four different time intervals. The percentages were calculated on the basis of the 
total radioactivities present in the digestive tract at each time as $100 \%$ and corrected for the recoveries from SDS-PAGE to represent specifically the amounts of intact lectin. Free lectins in stomach, small intestine 1 and 2 amount to $10-20 \%$ after 0.5 to $2 \mathrm{~h}$ of ingestion, and afterward most of them moved down to the lower small intestine, the caecum and the large intestine where the lectins were found to be largely in the free state. Little free lectin was found in stomach and small intestine 1 and 2 , after $24 \mathrm{~h}$ of ingestion. On the other hand, the distribution patterns of bound lectin indicate that a considerable part of the ingested Kintoki bean lectin quickly binds to the small intestine, and remains bound especially to small intestine 2 and 3 for at least $24 \mathrm{~h}$. The total amounts of the bound lectin were the highest, approximately $40 \%$ of the total present in the digestive tract, at $2 \mathrm{~h}$ after stomachintubation and about $20 \%$ were still bound after $24 \mathrm{~h}$. The bound lectin seems to be gradually liberated from the tissues with time. Little binding occurred in the stomach, the caecum and the large intestine.

2) Hemagglutinating activities of the lectins recovered from digestive tract after their stomach-intubation. The behavior of Kintoki bean lectin in the digestive tract was examined using $\left[{ }^{3} \mathrm{H}\right]$ lectin by identifying the lectin on SDSPAGE. The main conclusion drawn from this experiment is that the lectin ingested orally is not easily degraded, and moves in the gut with some being bound to the tissues. We have already proven that Kintoki bean lectin is toxic to cultured animal cells (15). If the lectin retains its activity during its passage through the gut, it will be possible for the active lectin to exhibit its toxicity on the epithelial cells in the small intestine. In an attempt to examine whether the lectin is still active in the gut after ingestion into the mouse, we assayed the hemagglutinating activities of the contents recovered from the gut mice administered with Kintoki bean lectin (Table 4). As lectin bound to the intestines could not be intentionally liberated for the assay, the

Table 4. Hemagglutinating activity recovered from contents of digestive tract $(\%)$.

\begin{tabular}{|c|c|c|c|c|}
\hline \multirow{2}{*}{ Organs } & \multicolumn{4}{|c|}{ Time (h) } \\
\hline & 0.5 & 2 & 5 & 24 \\
\hline Stomach & 25.0 & 3.1 & 0.8 & 0.4 \\
\hline Small intestine 1 & 12.5 & 3.1 & 3.1 & 0.8 \\
\hline 2 & 12.5 & 25.0 & 3.1 & 1.0 \\
\hline 3 & 6.3 & 3.1 & 12.5 & 6.3 \\
\hline Caecum & 1.6 & 2.2 & 12.5 & 25.0 \\
\hline Large intestine & 0.8 & 0.8 & 8.8 & 6.3 \\
\hline Faeces & - & - & - & 5.3 \\
\hline Urine & - & - & - & - \\
\hline Total recovery & 58.7 & 37.3 & 40.8 & 45.1 \\
\hline
\end{tabular}

$10 \mathrm{mg}$ lectin $(25,200$ units) was ingested by each mouse. Lectin bound to intestine was not taken into account.

Vol. 30, No. 4, 1984 
recovery was as low as $30 \%$ of the total activity ingested after $2 \mathrm{~h}$ of intubation when the binding was supposed to reach a maximum degree, while it increased gradually to $59 \%$ and $83 \%$ after 5 and $24 \mathrm{~h}$ of intubation, respectively, as the lectin once bound was released in vivo into the digestive contents with time as shown in Fig. 1.

If the bound lectins are taken into account on the basis of the results shown in Table 2 , the recoveries in the hemagglutinating activity will be over $70 \%$ in total at all the incubation periods. Consequently, it is concluded, as similarly as in the experiment on the movement of $\left[{ }^{3} \mathrm{H}\right]$ lectin in the gut, that the majority of the ingested lectin passes through the gut, retaining a large part of its hemagglutinating activity. Higuchi et al. reported similar results for winged bean lectin(6). It is noteworthy that the feces collected after $24 \mathrm{~h}$ of intubation contained some active lectin. About $30 \%$ of the ingested $\left[{ }^{3} \mathrm{H}\right]$ lectin was found in the feces as shown in Table 2, but the amounts calculated from the hemagglutinating activity represented only $7 \%$ (Table 4). Slow but steady progress of lectin digestion is suggested by the findings that only 65 to $70 \%$ of radioactivity represents the intact lectin in the caecum, large intestine and the feces after $24 \mathrm{~h}$ of intubation (Table 2).

\section{Binding to intestine in vitro}

Judging from the hemagglutinating activities of the contents of the gut, Kintoki bean lectin seemed not to be rapidly hydrolyzed in vivo. Therefore, there must be time enough for the lectin to exhibit its toxic functions before being inactivated in

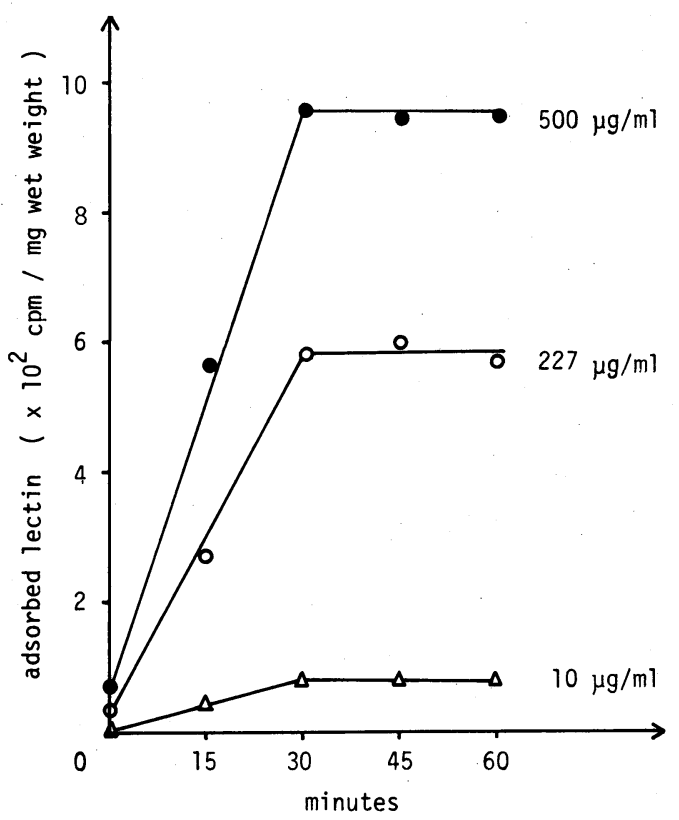

Fig. 2. Time course of the lectin binding to small intestine in vitro. Lectin concentration was $10 \mu \mathrm{g} / \mathrm{ml}(\triangle), 227 \mu \mathrm{g} / \mathrm{ml}(\bigcirc)$ and $500 \mu \mathrm{g} / \mathrm{ml}(\bullet)$. 


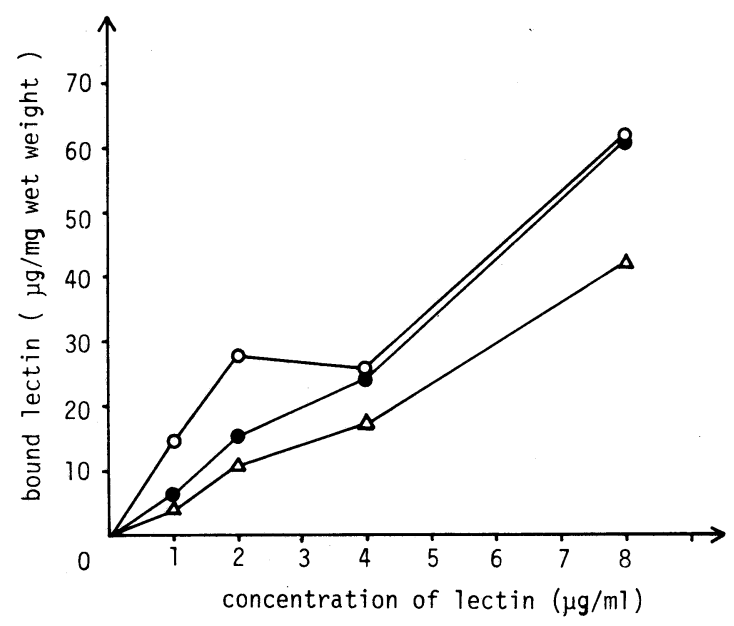

Fig. 3. Amounts of lectin bound to small intestine in vitro. Everted sacs of small intestine 1,2 and 3 were placed in lectin solutions of various concentrations for $30 \mathrm{~min} ; \bigcirc$, small intestine $1 ; \triangle$, small intestine 2 ;

-, small intestine 3 .

the digestive tract. When Kintoki bean lectin was orally ingested by mice, several physiological effects such as decreases in body weight and in the digestibility of major nutrients, and severe disruption of the epithelial cells in the small intestine were observed (8). In the present study, we monitored the time-course of the binding reaction using everted segments of small intestine and lectin solutions of 10,227 and $500 \mu \mathrm{g} / \mathrm{ml}$. The binding to the tissue proceeded quickly and reached a plateau after $30 \mathrm{~min}$, during which time the lectin must maintain its stability in the gut according to the above results (Fig. 2). Therefore, it is considered that the ingested Kintoki bean lectin must reveal its physiological activity on the epithelial cells before it is enzymatically degraded into the inactive forms. Everted segments of the 3 different parts of the small intestine were exposed to several lectin solutions of higher concentrations to see how much lectin could bind to each part of the intestine (Fig. 3). Little difference was found in the binding capacity of the various parts of the small intestine used. The amounts of bound lectin increased in proportion to the lectin concentration, saturation not occurring within the tested concentration ranges. These amounts represent about $15 \%$ of the lectin present in the solutions. This result is in good agreement with the above one in that about 10 to $20 \%$ of the ingested lectin became bound to the intestine after 0.5 and $2 \mathrm{~h}$ of incubation in an experiment with $\left[{ }^{3} \mathrm{H}\right] l$ lectin in vitro.

\section{Histological observation of the lectin binding to intestine}

1) Treatment in vivo. To ascertain the binding of the lectin to small intestine visually, mice were allowed to ingest FITC-lectin by stomach-intubation, and $2 \mathrm{~h}$ 

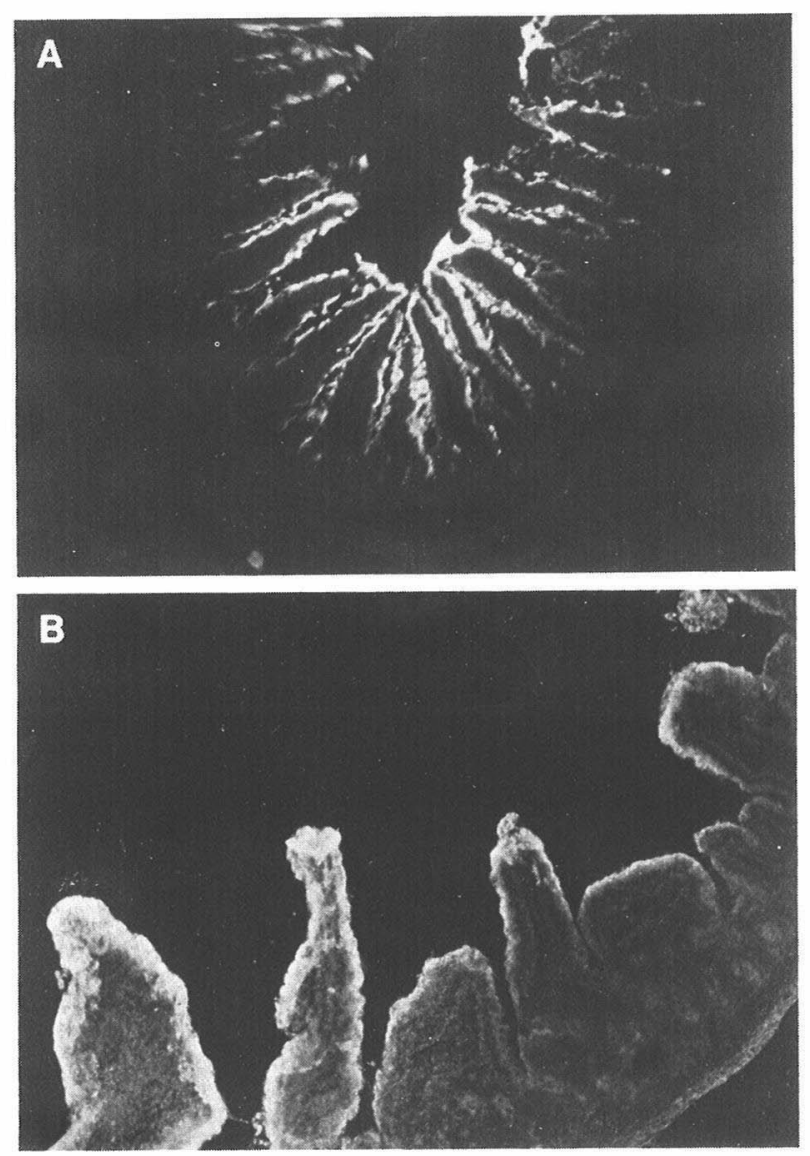

Fig. 4. A: A section of intestine $10 \mathrm{~cm}$ from pylorus of mouse fed FITC-lectin in vivo $(\times 40)$.

$\mathrm{B}$ : A section of intestine $2 \mathrm{~cm}$ from pylorus of mouse fed FITC-lectin in vitro $(\times 100)$.

later the small intestine was excised to prepare frozen sections of $10 \mu \mathrm{m}$ thickness. The sections were observed under a microscope through a FITC interference filter (Fig. 4 A). Fluorescence was observed at the surfaces of the villi, indicating that the lectin binds at the top and upper sides of the villi where dipeptidase, sucrase and other membrane digestive enzymes are localized (20). Hence, the lectin binding to these sites will surely result in such inhibition of the digestion and absorption of nutrients as previously reported (8).

2) Treatment in vitro. FITC-lectin was allowed to react with intestinal sections on a slide glass. Fluorescence was not observed inside the villi, but at the top and upper sides thereof as observed in vivo. Lectin appeared not to rapidly bind to the crypt. 
In conclusion, Kintoki bean lectin is neither hydrolyzed nor inactivated in the stomach but moves into the small intestine in an active form. In the small intestine, little is hydrolyzed and considerable amounts of the lectin bind to the intestinal mucosa. The bound lectin remains there for a relatively long period with little being absorbed or degraded. And a large portion of free lectins passes through the digestive tract, maintaining hemagglutinating activity. The binding of the lectin to intestinal epithelia must result in the retardation of the intestinal digestion and absorption of nutrients ( 8 ). In addition, Kintoki bean lectin depresses the rate of cell division as well as other general cell activities on the villi(15). Thereby, the oral toxicities of the lectin are considered to be brought about by the reduction of enzyme secretion(21) and finally by the inhibition of membrane degestionabsorption (19). A possibility of direct enzyme inhibition by this lectin has not yet been excluded. In our preliminary experiment, we observed a significant decrease in the transport of amino acids and sugars in the small intestine of mice having ingested Kintoki bean lectin. The mechanisms of the inhibition of nutrient absorption and other changes occurring following the binding of lectin to intestinal surfaces are under investigation in our laboratory.

\section{REFERENCES}

1) Santidrian, S., Marzo, F., Lasheras, B., Cenarruzabeitia, M. N., and Larralde, J. (1980): Growth rate and composition of skeletal muscle of chickens fed different raw legume diets. Growth, 44, 336-342.

2) Kimura, T., Satanachote, C., and Yoshida, A. (1982): Effect of feeding raw Winged bean seeds on gastrointestinal functions in rats. J. Nutr. Sci. Vitaminol., 28, 27-33.

3) Liener, I. E. (1976): Legume toxins in relation to protein digestibility-a review. J. Food Sci., 41, 1076-1081.

4) Jaffe, W. G. (1980): Hemagglutinins (Lectins), in Toxic Constituents of Plant Foodstuffs, ed. by Liener, I. E., Academic Press, New York, pp. 73-102.

5) Guillaume, J. (1977): Use of field beans Vicia faba L. and peas (Pisum sativum) in laying hen and growing chicken diets, in Protein Quality from Leguminous Crops Publication No. EUR 5686 EN, Commision of the European Communities, Luxembourg, pp. 217-234.

6) Griffiths, D. W. (1979): The inhibition of digestive enzymes by extracts of field beans (Vicia faba L.). J. Sci. Food Agric., 30, 558-562.

7) Hara, T., Tsukamoto, I., and Miyoshi, M. (1983): Oral toxicity of Kintoki bean (Phaseolus vulgaris L.) lectin. J. Nutri. Sci. Vitaminol., 29, 589-599.

8) Osawa, T. (1976): Lectin, in Lectin in Japanese, ed. by Osawa, T., and Mori, R., Kodansha, Tokyo, pp. 1-13.

9) Simpson, D. L., Thorne, D. R., and Loh, H. H. (1978): Lectins: Endogenous carbohydrate-binding proteins from vertebrate tissues: Functional role in recognition processes? Life Sci., 22, 727-748.

10) Goddard, V. R., and Mendel, L. B. (1929): Plant hemagglutinins with special reference to a preparation from the navy bean. J. Biol. Chem., 82, 447-463.

11) Romero, J., and Ryan, D. S. (1978): Susceptibility of the major storage protein of the

Vol. 30, No. 4, 1984 
bean, Phaseolus vulgaris L. to in vitro enzymatic hydrolysis. J. Agric. Food Chem., 26, 784-788.

12) Brady, P. G., Vannier, A. N., and Banwell, J. G. (1978): Identification of the dietary lectin, wheat germ agglutinin, in human intestinal contents. Gastroenterology, 75, 236-239.

13) Lorenzsonn, V., and Olsen, W. A. (1982): In vivo responses of rat intestinal epithelium to intraluminal dietary lectins. Gastroenterology, 82, 838-848.

14) Miyoshi, M., Nakabayashi, J., Hara, T., Yawata, T., Tsukamoto, I., and Hamaguchi, Y. (1982): The lethal protein from Kintoki beans (Phaseolus vulgaris) identified as a lectin. J. Nutr. Sci. Vitaminol., 28, 255-264.

15) Yawata, T., Hara, T., Tsukamoto, I., and Miyoshi, M. (1983): Toxic effects of Kintoki bean (Phaseolus vulgaris) lectin on cultured animal cells. J. Nutr. Sci. Vitaminol., 29, 65-74.

16) Hamaguchi, Y., Yagi, N., Nishino, A., Mochizuki, T., Mizukami, T., and Miyoshi, M. (1977): The isolation and characterization of a lethal protein from Kintoki beans (Phaseolus vulgaris L.). J. Nutr. Sci. Vitaminol., 23, 525-534.

17) Putzai, A., Clarke, E. M. W., Grant, G., and King, T. P. (1981): The toxicity of Phaseolus vulgaris lectins. Nitrogen balance and immunochemical studies. J. Sci. Food Agric., 32, 1037-1046.

18) Ugolev, A. M., and Lay, P. D. (1973): Membrane digestion. A concept of enzymic hydrolysis on cell membranes. Biochim. Biophys. Acta, 300, 105-128. 